\title{
Empirical study of project management dimensions: guidelines for an adapted standard to SMEs and large enterprises in developing countries (Moroccan case)
}

\author{
Amina Oukennou ${ }^{1}$, Zitouni Beidouri $^{2}$ and Otmane Bouksour ${ }^{3}$ \\ ${ }^{1}$ Mechanical \& Industrial Engineering Laboratory Department, School of Technology Casablanca, Hassan II University of
} Casablanca, PO Box 8012, Oasis, Casablanca, Morocco

${ }^{2}$ Mechanical \& Industrial Engineering Laboratory Department, School of Technology Casablanca, Hassan II University of Casablanca, PO Box 8012, Oasis, Casablanca, Morocco

${ }^{3}$ Mechanical \& Industrial Engineering Laboratory Department, School of Technology Casablanca, Hassan II University of Casablanca, PO Box 8012, Oasis, Casablanca, Morocco

\begin{abstract}
Small to Medium-sized enterprises are a very important component of the economy. They are present in the whole industries all over the world. They are considered as the engine for future growth in the economy. Project management is an economical international factor impacting all types of enterprises including the SMEs.

The aim of this paper is to measure the weight of using projects and project management in Moroccan SMEs in comparison with the large companies.

This study is based on interviews with experts: project managers, managers, directors, and consultants. They were asked questions measuring the weight of using projects, the level of using project management, and the resources employed. Eighteen Moroccan companies from a range of industries and sizes were consulted.

All the companies consider projects as a key element in their strategy. Most of them affirm the great usefulness of the approach " project » especially for the external activities. The main differences lie in the duration and the size of used projects. Despite the common shared idea about the importance of the project management, the interviewed persons believe that the project management knowledge has the same importance or less than the technical knowledge. All the companies affirm the need of a simpler version of project management. Despite the fact that the suggested content varies from one company to another, several similarities exist.

Keywords: Project Dimension, Project Management, Small to Medium-Sized Enterprise, Morocco.
\end{abstract}

\section{Introduction}

SMEs constitute the largest segment of industry in most nations [1].
According to the Moroccan ministry of Industry, Trade, and New Technologies, more than $95 \%$ of Moroccan companies are SMEs" Small to Medium-sized enterprises "[2].

According to a study realized by of the Organization for Economic Co-operation and Development (OECD) in Morocco in 2009:

-Over than $90 \%$ of the industrial companies are SMEs.

- SMEs contributes more than $40 \%$ to the turn over of the industrial sector.

-SMEs employ more than $50 \%$ of the workforce [3].

These statistics prove the importance of the SMEs.

Facing the rapid change environment, SMEs continuously look for ways to survive, grow, and be competitive [4]. Searching or creating projects is one way from others. Turner and Al (2009) demonstrated that the SMEs spent about the third of their turnover on projects [5].

This study has the objective of responding to these questions:

-Do projects have the same importance in Moroccan large and Small to Medium-Sized Enterprises?

-To what extent the project management is used in Moroccan large and Small to Medium-Sized Enterprises? -What are the characteristics of the required version of project management for SMEs?

This paper will be organized in this way:

1-We start with definition(s) of Moroccan SME.

2-Then we describe the methodology we applied.

3-Finally we present the findings of the study. 


\section{SMEs in Morocco}

\subsection{Definition}

Until July 2002, there was no official definition of the SMEs in Morocco. The first law was named the 53-00. It was a charter of small and medium enterprises.

The law defines the SME as a Moroccan company respecting the conditions:

- To have a permanent employees number not exceeding 200 persons

- To have achieved over the last two years, a turnover less than 75 million Moroccan dirhams [6]

The SMEs committee director, in the General Confederation of Moroccan Enterprises, has confirmed the same definition during the Local Med Tetouan seminar in 2015 [7]

\subsection{Methodology}

The paper is a part of a large study where we used a methodical approach based on five main steps:

1.Literature review to have an idea about project and project management in SMEs in Morocco and all over the world.

2.Comparison between the SMEs and the large Moroccan companies concerning project and project management 3.Extension of the findings using a large survey and making a focus on SMEs

4.Description of an adapted project management version to Moroccan SMEs

5.Confirming the proposal

During this stage (2nd step), we used a qualitative method. The method provides insights into the project management concept and helps to develop hypotheses for potential quantitative research (3rd step).

We interviewed people from SMEs and large companies. Different sizes and industries were included in our sample.

We asked them information about their professional and academic background, about the company and the department where they are working, about the dimensions of project and project management: turnover, projects duration, annual number of projects, and resources. Finally, we discussed their position in relation to standards, tools, and the need of having what named Turner and Al « lite version » [8] of project management.

\section{Interviewed People}

In order to guarantee a certain level of information quality, selected people to be interviewed had to respect some criteria:

-They have worked in projects at least ones during their career as (project team members, project managers, executives or directors).

- They have at least a diploma of engineer to guarantee they have a minimal project management knowledge.

- They are from different level of management.

-They are from different levels of seniority.

Table 1 present a summary of interviewed people.

\begin{tabular}{|c|c|c|c|}
\hline $\begin{array}{l}\text { Member } \\
\text { level }\end{array}$ & $\begin{array}{c}\text { Experience } \\
\text { duration }\end{array}$ & $\begin{array}{c}\text { Project } \\
\text { management } \\
\text { Experience } \\
\text { duration }\end{array}$ & $\begin{array}{c}\text { Management } \\
\text { level }\end{array}$ \\
\hline $\begin{array}{c}\text { Team } \\
\text { Member }\end{array}$ & 2 & 2 & $\begin{array}{c}\text { Software } \\
\text { engineer }\end{array}$ \\
\hline $\begin{array}{l}\text { Project } \\
\text { manager }\end{array}$ & 5 & 2 & $\begin{array}{c}\text { Quality project } \\
\text { manager }\end{array}$ \\
\hline $\begin{array}{l}\text { Project } \\
\text { manager }\end{array}$ & 10 & 2 & Scrum Master \\
\hline $\begin{array}{l}\text { Project } \\
\text { manager }\end{array}$ & 10 & 2 & $\begin{array}{c}\text { Project } \\
\text { manager }\end{array}$ \\
\hline $\begin{array}{l}\text { Project } \\
\text { manager }\end{array}$ & 10 & 2 & Chief executive \\
\hline $\begin{array}{l}\text { Project } \\
\text { manager }\end{array}$ & 13 & 3 & $\begin{array}{l}\text { Organization } \\
\text { manager }\end{array}$ \\
\hline $\begin{array}{c}\text { Project } \\
\text { manager }\end{array}$ & 10 & 5 & $\begin{array}{l}\text { Quality } \\
\text { manager }\end{array}$ \\
\hline $\begin{array}{l}\text { Project } \\
\text { Director }\end{array}$ & 10 & 6 & $\begin{array}{l}\text { Expansion } \\
\text { manager }\end{array}$ \\
\hline Consultant & 8 & 8 & Consultant \\
\hline $\begin{array}{l}\text { Project } \\
\text { Director }\end{array}$ & 13 & 8 & Chief executive \\
\hline $\begin{array}{l}\text { Project } \\
\text { manager }\end{array}$ & 9 & 8 & $\begin{array}{l}\text { Project } \\
\text { manager }\end{array}$ \\
\hline $\begin{array}{l}\text { Project } \\
\text { manager }\end{array}$ & 9 & 9 & Expert \\
\hline $\begin{array}{l}\text { Project } \\
\text { Director }\end{array}$ & 15 & 10 & Manager \\
\hline $\begin{array}{l}\text { Project } \\
\text { manager }\end{array}$ & 13 & 11 & $\begin{array}{c}\text { Senior project } \\
\text { manager }\end{array}$ \\
\hline $\begin{array}{l}\text { Project } \\
\text { Director }\end{array}$ & 21 & 12 & Chief executive \\
\hline $\begin{array}{l}\text { Project } \\
\text { Director }\end{array}$ & 15 & 14 & Chief executive \\
\hline $\begin{array}{l}\text { Project } \\
\text { manager }\end{array}$ & 14 & 14 & $\begin{array}{l}\text { Logistic } \\
\text { manager }\end{array}$ \\
\hline $\begin{array}{l}\text { Project } \\
\text { Director }\end{array}$ & 15 & 15 & Chief executive \\
\hline
\end{tabular}

The second remark is that project management experience is generally shorter than the whole experience, which mean that any employee needs to serve as a technical employee before having the position of a project manager and that it is rarely possible to start as a project manager. A remark that will be affirmed in the next sections. 
All the members have accepted to be named project managers except one member who has a good level in project management but refuses the role of project manager. He believes in new agile concepts and prefers to be named consultant even if he is the project leader.

We interviewed people from SMEs and large companies, with different sizes and from different industries.

\section{Sample Campanies}

The interview was a list of questions about many aspects of project and project management. The first parts concerned the interviewed persons. The others concern the companies' information and the practice of project management.

Table 2 gives an idea of these surveyed companies.

Table 2: Surveyed companies

\begin{tabular}{|c|c|c|c|c|c|}
\hline Name & Type & $\begin{array}{l}\text { Activity } \\
\text { area }\end{array}$ & $\begin{array}{c}\text { Turnover } \\
\text { (million } \\
\text { MAD } \\
\text { Moroccan } \\
\text { Dirham)* }\end{array}$ & $\begin{array}{c}\text { Number } \\
\text { of } \\
\text { employees }\end{array}$ & $\begin{array}{l}\text { Interviewed } \\
\text { Entity }\end{array}$ \\
\hline $\mathrm{CD}$ & Large & Agri-food & 9000 & 7000 & QHSE \\
\hline I C & Large & Telecom & 7000 & 1100 & IP Stream \\
\hline W A & Large & Insurances & 6000 & 300 & $\begin{array}{c}\text { Information } \\
\text { system }\end{array}$ \\
\hline $\mathrm{M} \mathrm{C}$ & Large & Telecom & 5500 & 1160 & $\begin{array}{c}\text { Special } \\
\text { Infrastructure } \\
\text { projects }\end{array}$ \\
\hline $\mathrm{M} \mathrm{C}$ & Large & Telecom & 5500 & 1160 & $\begin{array}{c}\text { Information } \\
\text { system }\end{array}$ \\
\hline M C & Large & Telecom & 5500 & 1000 & $\begin{array}{c}\text { Data and } \\
\text { voice } \\
\text { services }\end{array}$ \\
\hline LF & Large & $\begin{array}{c}\text { Construction } \\
\text { materials }\end{array}$ & 5000 & 1000 & $\begin{array}{l}\text { Supply } \\
\text { Chain }\end{array}$ \\
\hline DET & Large & $\begin{array}{c}\text { Retail } \\
\text { industry }\end{array}$ & 450 & 450 & Expansion \\
\hline S M & Large & $\begin{array}{c}\text { Audio- } \\
\text { visual }\end{array}$ & 300 & 800 & $\begin{array}{l}\text { The whole } \\
\text { Enterprise }\end{array}$ \\
\hline $\mathrm{OT}$ & SME & $\begin{array}{c}\text { SI } \\
\text { consulting }\end{array}$ & 200 & 20 & $\begin{array}{l}\text { The whole } \\
\text { Enterprise }\end{array}$ \\
\hline I CM & SME & $\begin{array}{l}\text { Network } \\
\text { Installer }\end{array}$ & 170 & 120 & $\begin{array}{l}\text { The whole } \\
\text { Enterprise }\end{array}$ \\
\hline $\mathrm{TE}$ & SME & $\begin{array}{c}\text { Industrial air } \\
\text { conditioning } \\
\text { and cooling } \\
\text { systems }\end{array}$ & 30 & 20 & $\begin{array}{l}\text { The whole } \\
\text { Enterprise }\end{array}$ \\
\hline DF & SME & Finance & 22 & 20 & $\begin{array}{l}\text { The whole } \\
\text { Enterprise }\end{array}$ \\
\hline SES & SME & Aerospace & 5 & 150 & $\begin{array}{l}\text { The whole } \\
\text { Enterprise }\end{array}$ \\
\hline
\end{tabular}

\begin{tabular}{|c|c|c|c|c|c|}
\hline V C & SME & $\begin{array}{c}\text { Recruitment, } \\
\text { Training, } \\
\text { Project } \\
\text { Coaching }\end{array}$ & 3.5 & 1 & $\begin{array}{c}\text { The whole } \\
\text { Enterprise }\end{array}$ \\
\hline MCC & SME & $\begin{array}{c}\text { Training and } \\
\text { consulting }\end{array}$ & 3 & 7 & $\begin{array}{l}\text { The whole } \\
\text { Enterprise }\end{array}$ \\
\hline C S & SME & IT services & 1.5 & 10 & $\begin{array}{l}\text { The whole } \\
\text { Enterprise }\end{array}$ \\
\hline SM & SME & $\begin{array}{c}\text { Informatics } \\
\text { services }\end{array}$ & 1 & 2 & $\begin{array}{l}\text { The whole } \\
\text { Enterprise }\end{array}$ \\
\hline
\end{tabular}

The sample covers different areas and contains large and small enterprises.

The choice of including the large companies in the survey was done because:

-There is a big relation of interaction between large and small companies in the Moroccan market

-The majority of the Moroccan officials in Moroccan companies work first in large firms before creating their own start up.

-To speak about differences in project management between large firms and SMEs suppose that we have information about the two types of enterprises.

\section{Nota Bene}

To get maximum benefit of the large companies' information and to be closer to the SMEs context, we used an approach of « entity » instead of the whole enterprise.

\section{Project Dimension}

To measure this aspect, we defined four criteria:

-Project use

-Project target

-Dimensions of projects (Projects number, Project duration and Project resources)

\subsection{Project Use}

The first remark is that all the companies work in project mode regardless of their size and their activity sector. The percentage of projects turnover is largely higher than the percentage of operations turnover. There were three exceptions: 2 large companies and a small one. The first company is a construction equipment manufacturer. They have construction factories with repetitive activities.

The second was an agri-food company. Even if the number of projects is high, the quality department has constraints of keeping a good level of quality. The company invests more in the analysis of the products they market. The last exception is a SME in training and consulting. This 
company tries to diversify their activities. So it invests in repetitive and stable operations.

\subsection{Project Target}

We tried to make a classification of internal and external projects. The remarkable finding is that internal projects are rare in SMEs. Their percentage is lower than $20 \%$. This is due to that the SME needs external projects to survive and due to its small size it considers internal projects as secondary.

\subsection{Dimensions of projects}

Knowing that the projects are mostly used, we tried to have an idea about the dimensions of the projects within the companies. We tried to measure the average number of projects by year, the average duration of a project and the average number of resources required to carry out a project.

Projects Number: The results show low correlation between the company size or its activity sector and the number of projects. idem for the industry type. Half of the companies have an average of projects less than 10 projects by year. The other half between 10 and 60 . The Telecom installer was the alone company saying they have an average of three hundred projects by year, if we count the shortest projects.

Projects Duration: The results of the interviewed sample were divided into three categories: less than one year, an average of one year and more than 2 years. We noticed that the SMEs have a tendency to use projects of small duration. If we count the small projects (the duration is shorter than a month).

Number of Projects Employees: There is a close relationship between the duration of the projects and the number of human resources devoted to these projects. Long projects need a big number of resources.

All employees of the companies have projects on which they work. The same resources work on several projects in addition to daily operational work.

\subsection{Summary}

We can summarize all obtained results as presented in Table 3:

- We have the same importance of projects as for SMEs as for the large companies

-The SMEs work more with external projects

-The number of projects, the budget, and their duration can define the dimension of projects.

-Except the number of projects, all the dimensions depend on the size of the company.
Table 3: Surveyed companies

\begin{tabular}{|c|c|c|c|}
\hline $\begin{array}{l}\text { Member } \\
\text { level }\end{array}$ & Level & $\begin{array}{c}\text { Project } \\
\text { management } \\
\text { Experience } \\
\text { duration }\end{array}$ & $\begin{array}{c}\text { Manageme } \\
\text { nt level }\end{array}$ \\
\hline \multirow[b]{2}{*}{ Project Use } & Projects & ++ & ++ \\
\hline & Operations & - & $\begin{array}{c}\text { Depends on } \\
\text { the sector } \\
\text { activitys }\end{array}$ \\
\hline \multirow[b]{2}{*}{$\begin{array}{l}\text { Project } \\
\text { Target }\end{array}$} & External & ++ & ++ \\
\hline & Internal & -- & $\begin{array}{c}\text { Depends on } \\
\text { the entity } \\
\text { type }\end{array}$ \\
\hline \multirow[b]{3}{*}{$\begin{array}{c}\text { Project } \\
\text { dimensions }\end{array}$} & Number & \multicolumn{2}{|c|}{ Independent of the size } \\
\hline & Duration & Short & Variable \\
\hline & Employees & \multicolumn{2}{|c|}{ Related to the project duration } \\
\hline
\end{tabular}

\section{Project Management Dimension}

To describe project management extent of use, multiple parameters have been chosen:

-The use of project management including the recruitment process, the use of project management as an official process, and the existence of dedicated project management structure

-The position of the top management of project management

-The use of standards

\subsection{Use of Project Management}

We were looking for the answer to the question of project management use. The answer was positive for all the participants. The difference lay on the level of the use and what are conditions required before saying we use project management. There were two exceptions: two large firms (Agri-food and insurance) where the project management is defined as an official process but not used a lot. The reasons were that the employees have a low academic background to use literally the process. The second case is an IT department in an insurance company. The constraints of time do not give employees a chance to use formalities of project management.

Then we asked if the project management is an official process in the company. The large number confirming that, was from the large companies. The SMEs do not have this maturity. There were three exceptions justified as 
follows: one SME is a subsidiary of an international group and apply the group policies. Another SME has a mission of project consulting and help companies to use project management. The last exception is a project-oriented company.

Among all the companies, one SME has a dedicated entity. The remaining are large companies. Globally, the existence of a project management dedicated entity is related to the level of using project management.

Our last question was the percentage of management knowledge and technical knowledge. The answer showed a low level of importance of management notions generally and project management specifically. All the companies require a good level in technical knowledge before thinking to management knowledge. The reasons were that the final consumer is more rigorous about the technical requirements than the management aspect, and that the management knowledge can be learned then by experience.

\subsection{The Position of the Top Management of Project Management management}

All the answers confirm that the top management has a good knowledge about the project management. It exceeds to the program and portfolio management. This does not mean that the boss (CEO or founder) supports the use of project management. It depends on the size and the importance of the projects and his available time. Many bosses devote almost all of their time to daily activities. The same result is valid for the SMEs and for the large companies.

\subsection{Summary}

We can sum up the project management dimensions as presented in the table 4:

-Except the project number, all the dimensions depend on the size of the company.
Table 4: Project Dimension

\begin{tabular}{|c|c|c|c|}
\hline & & SMEs & $\begin{array}{l}\text { Large } \\
\text { companies }\end{array}$ \\
\hline \multirow{5}{*}{$\begin{array}{l}\text { Use of project } \\
\text { management }\end{array}$} & Direct use & ++ & ++ \\
\hline & $\begin{array}{l}\text { Official } \\
\text { process }\end{array}$ & - & ++ \\
\hline & $\begin{array}{c}\text { Dedicated } \\
\text { Entity }\end{array}$ & -- & + \\
\hline & \multirow[t]{2}{*}{ Recruitment } & Technical++ & Technical++ \\
\hline & & Management-- & Management-- \\
\hline \multirow{2}{*}{$\begin{array}{l}\text { Top } \\
\text { management }\end{array}$} & Supporting & +++ & + \\
\hline & Reasons & $\begin{array}{c}\text { Time } \\
\text { constraints }\end{array}$ & $\begin{array}{c}\text { Project } \\
\text { importance and } \\
\text { size }\end{array}$ \\
\hline
\end{tabular}

\section{The new Version, Tools, and Technics}

Before speaking about the need of a new adapted model of project management, we asked people about the use of standards. Then we tried to know the tools and technics they use. Finally we asked if is there a need to have a project management version adapted to their needs, and try to define its characteristics and contents.

\subsection{The Use of Standards}

As waited, the majority does not have a project management standard to follow. Two companies use a combination of standards. Just three companies confirmed to have an internal process of project management. All of them are subsidiaries of international groups; they have the process of the mother company.

We also asked people about the factors impacting the use of standards.

Table 5 sums up these factors. 
Table 5: Factors impacting the use of Standards

\begin{tabular}{|c|c|c|c|c|}
\hline & $\begin{array}{l}\text { Technical } \\
\text { factors }\end{array}$ & $\begin{array}{l}\text { Cultural } \\
\text { factors }\end{array}$ & $\begin{array}{l}\text { Economic } \\
\text { factors }\end{array}$ & $\begin{array}{c}\text { Political } \\
\text { factors }\end{array}$ \\
\hline 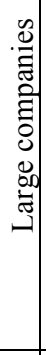 & $\begin{array}{c}\text { Unknown } \\
\text { standards } \\
\text {-Inadequate } \\
\text { academic } \\
\text { qualifications } \\
\text {-Great level of } \\
\text { abstraction }\end{array}$ & $\begin{array}{c}\text { Top } \\
\text { management } \\
\text { does not care } \\
\text { and sees only } \\
\text { the result } \\
\text { The "standard" } \\
\text { is not a } \\
\text { common idea in } \\
\text { Morocco } \\
\text { Difference of } \\
\text { cultures }\end{array}$ & $\begin{array}{l}\text { Different } \\
\text { economic levels } \\
\text { High cost of } \\
\text { training } \\
\text { Insufficient } \\
\text { funding } \\
\text { Expensive } \\
\text { models }\end{array}$ & $\begin{array}{l}\text { Not suitable } \\
\text { political } \\
\text { environment }\end{array}$ \\
\hline$\sum_{\infty}^{1}$ & $\begin{array}{l}\text { Too Heavy (A } \\
\text { lot of details) } \\
\text { It Does not } \\
\text { determine } \\
\text { how to be } \\
\text { used } \\
\text { Undefined } \\
\text { tools } \\
\text { Staff with low } \\
\text { level of } \\
\text { knowledge } \\
\text { Very } \\
\text { Complicated }\end{array}$ & $\begin{array}{l}\text { Absence of } \\
\text { team spirit } \\
\text { The overlap } \\
\text { between what is } \\
\text { personal and } \\
\text { professional } \\
\text { Presence of the } \\
\text { emotional } \\
\text { dimension } \\
\text { The language } \\
\text { used in the } \\
\text { project } \\
\text { management } \\
\text { world is not } \\
\text { adapted to the } \\
\text { Moroccan } \\
\text { context } \\
\text { Absence of the } \\
\text { concept of time } \\
\text { management } \\
\text { Dominance of } \\
\text { inadequate } \\
\text { culture }\end{array}$ & $\begin{array}{l}\text { Expensive } \\
\text { training } \\
\text { Requires } \\
\text { Qualified } \\
\text { resources } \\
\text { Lack of budget } \\
\text { Under- } \\
\text { developed } \\
\text { country: The } \\
\text { SMEs priority } \\
\text { is to survive } \\
\text { Costly } \\
\text { implementation }\end{array}$ & $\begin{array}{l}\text { Corruption } \\
\text { Unable to } \\
\text { absorb } \\
\text { change: the } \\
\text { dictatorship }\end{array}$ \\
\hline
\end{tabular}

To summarize: all companies raise issues related to the complexity of well-known project management standards, high costs of training and licensing, and cultural differences. What is new and unexpected is that large companies claim to have the same problems as SMEs. The difficulties are mainly related to the differences between the contexts of companies in developed and developing countries such as Morocco.

\subsection{Guidelines for a New Version Of Project Management}

Characteristics of the New Standard: The logical consequence of the existence of problems with the existing standards, cited above, suggests the search for a new standard of project management adapted to the reality of the companies in developing countries like Morocco. The main characteristics of such a standard are:

-Simpler, flexible, more adapted « to the company size, dedicated for small teams $»$.
-Well documented and suitable for all levels of SMEs employees as 'It is widely accepted that employees in small business suffer from a lack of knowledge and skills' [9]

-It has to take into account the companies constraints "the workload, resources, competences... “

Content of The New Standard: The The difference depending on the size of the companies become clearer. The large companies proclaim they need all the elements of project management. The new thing they add is that it has to be presented in a simple way.

SMEs are more selective in the application of project management concepts. The common elements among all companies were: time, cost management, monitoring and tools to implement the methodology.

Summary: The new standard of project management has to be simpler and adapted. Its content has to be more restricted to the essential requirements of the SMEs: the time, the cost management, monitoring and tools.

\section{Limitations}

During the interviews we met two types of limitations:

-Limitations dicted by the nature of the SMEs and their characteristics such as the absence of data throughout the enterprise's life cycle.

-Limitations decided by the person interviewed. We had difficulties to convince SME owners to speak about the enterprise turnover. We also met people who refuse to give us information because of data confidentiality.

\section{Conclusions}

The project management practices encountered in SMEs and large Moroccan companies have the following characteristics:

-As in the large companies, the SMEs use projects as an element important for their growth.

-The SMEs. use external projects more than internal projects.

-The dimensions of projects can be defined as the number of projects, their duration and the number of resources employed. They differ from one company to another. The number of projects does not depend on the size of the company on the contrary of the project duration which is generally shorter for SMEs (due to the resources constraints). 
Because they use projects, project management become an obligation for all the types of companies. The differences lie in the level of maturity of using the discipline:

-The use project management as an official process is rarely encountered in SMEs. It is more acceptable in the large firms where it is easy to find a dedicated entity to manage projects.

-During the recruitment process, the technical knowledge is considered more important than the management knowledge.

-The use of top management is considerable in the SMEs, it is constrained by the availability of time. In the large firms, the support of the top management depends on the size and importance of the projects.

-All the companies proclaim the complexity of the wellknown standards of project management, the expensive costs of the training and licensing, and the differences between cultures.

- They affirm they need a new version simpler and adapted to their needs. Its content has to be more restricted to the essential requirements of the SMEs: the time, the cost management, monitoring and tools.

\section{Implications and Future Steps}

All the companies proclaim The next work to do is to concentrate on the SMEs as the main agent of the study:

-To confirm the findings discussed bellow for a large number of SMEs

-To combine the obtained results with the new methodologies as agile methods and lean start-up

- To make a proposal of a first draft of an adapted version

\section{References}

[1] R. Suren Wadhwa, "Quality Green, EMS and lean synergies: sustainable manufacturing within SMEs as a case point", International Journal of Computer Science Issues, Vol. 11, No 2, 2014,pp.114-119

[2] http://www.mcinet.gov.ma/Industrie/Pages/Comp\%C3\%A9t itivit\%C3\%A9desPME.aspx, Moroccan Ministry of Industry, Trade, \& New Technologies site, Rabat,MoroccoA.

[3] Caisse Centrale de Garantie, «Experience du Maroc pour promouvoir la croissance et l'innovation des PME", The Organisation for Economic Co-operation and Development (OECD), Paris, France. https://www.oecd.org/mena/competitiveness/

[4] FJ Lin, YH Lin, "The effect of network relationship on the performance of SMEs", Journal of Business Research, 2015,Vol. 69, pp. 1780-1784, May 2016.

[5] J. Rodney Turner, A. Ledwith, J.Kelly, (2009) "Project management in small to medium - sized enterprises: A comparison between firms by size and industry", International Journal of Managing Projects in Business, Vol. 2 Iss: 2, pp. $282-296$

[6] http://www.ammc.ma/ (Autorité Marocaine du Marché des Capitaux), Rabat, Morocco
[7] S. HAMOUMI ,2015, " La culture d'Entreprise Au MAROC » Local Med Tétouan seminar, Tétouan,Morocco. [Online]. Available: http://cat.plateforme-localmed.net/, the June 20,2016http://cat.plateforme-localmed.net/

[8] J. Rodney Turner, A. Ledwith, J.Kelly, 2010, "Project management in small to medium-sized enterprises: Matching processes to the nature of the firm", International Journal of Project, Vol.28, pp.744-755, December 2010.

[9] Omanga Cleophas Mochoge," SMEs' Adoption Of WebBased Marketing: Empirical Evidence From Kenya", International Journal of Computer Science Issues, Vol. 11, No 2, 2014,pp.226-236 